\title{
Lady Parachutists and the End of Civilisation in Queensland
}

\author{
Bill Metcalf
}

Brisbane was wiped off the face of the Earth and Queensland ceased to exist as a political entity under the combined military forces of Victoria and New South Wales during violent conflict at the end of the twentieth century. Brisbane was annihilated because of the un-Christian sins of its people, and the moral corruption of its leaders. The Queensland Defence Force was incapable of defending even itself, let alone defeating the invading troops. The pivotal event in this collapse concerned the alluring performances by a group of 'lady parachutists' who entertained the Queensland military forces, thereby distracting them and allowing the opposing forces to easily defeat them at the Battle of Fort Lytton.

That, at least, is the key to the plot of Dr Thomas Pennington Lucas's 1894 dystopian novel The Ruins of Brisbane in the Year 2000.' The origin of this 'lady parachutists' myth, and the connections between this myth and the end of Queensland civilisation, led me to research a fascinating episode in Queensland's cultural history, and in particular Victorian notions of sexual propriety, 'true manhood' and the combined - albeit veiled - threats posed by unfettered female sexuality and male masturbation.

In early 1890, a group of American entertainers, led by 'Professor' Van Tassel, toured Australia putting on shows which combined gymnastic performances, music, roller-skating and swordsmanship. Park Van Tassel was a bartender and showman from Albuquerque, New Mexico. The central event of the show was the ascent of a scantily clad 'lady parachutist', Miss Van Tassel, in a hot-air balloon, and her return to Earth by parachute, while all the time performing daredevil stunts on a trapeze bar. ${ }^{2}$

Park Van Tassel did have a daughter, Jenny, who did parachute jumps from balloons, but the two young women who travelled with him in Australia and who performed under the stage names of Miss Valerie and Miss Gladys Van Tassel were actually Valerie and Gladys Freitas. At times, Park Van Tassel referred to them as his daughters and at other times claimed they were his sisters, but they 
were neither and the real relationship between Van Tassel and the Freitas sisters is unknown. ${ }^{3}$

By 1890 , balloon ascents and parachute descents were becoming a well-known form of entertainment throughout Europe and North America - although this art was still little known in Australia. There were two methods of ascension: using hot air or a lighter-than-air gas, usually either hydrogen or coal gas. The first recorded hot-air balloon ascent had been made in France in 1783, when François Pilâtre de Rozier and François Laurent flew over Paris for 23 minutes in a balloon built by Joseph and Étienne Montgolfier. The first gas balloon flight, using hydrogen, was made by Professor Jacques Alexandre César Charles and Nicolas-Louis Robert in 1783, also in France. André Jacques Garnerin made the first confirmed parachute descent on 22 October 1797 from above Parc Monceau, Paris. In November 1798 his wife, Jeanne Genevieve Labrosse, became the first woman to pilot a balloon, and the first woman to make a parachute descent.

The first Australian balloon ascent was by Joseph Dean, in Melbourne on 1 February 1858, using coal gas. A vast crowd watched as Dean's balloon became 'a mere speck, a homeopathic globule in the far distance, serenely and steadily sailing onwards, as though native to and rejoicing in the buoyant element' ${ }^{4}$ Henri L'Estrange is credited with making the first accidental parachute descent in Australia, when his balloon burst over Melbourne on 14 April $1879,{ }^{5}$ while John T. Williams, a Sydney watchmaker, made the first deliberate parachute jump in Australia, from a height of almost 2000 metres over Ashfield Recreation Ground in Sydney on 8 December $1888 . .^{6}$ Both L'Estrange and Williams had gone aloft in balloons filled with coal gas. The first parachute jump in Australia by a woman was made by Valerie Freitas, using the stage name of Valerie Van Tassel, at the Newcastle Racecourse on Saturday, 8 February 1890 . She was also the first woman to make a parachute jump in Queensland over the Brisbane Exhibition Grounds late on the afternoon of Thursday, 22 May $1890 .^{7}$

The dramatic parachute performances of the two Misses Van Tassel had been well received over several months in the southern colonies of Australia, but they ran into major problems while performing in Queensland. On Monday, 26 May 1890, 12-year-old Thomas Reid, of Arthur Street, Fortitude Valley, was killed when one of Van Tassel's poorly erected wooden poles, which was being used to suspend the inflating balloon, fell into the crowd of spectators. Although Professor Van Tassel and his crew were clearly negligent, Van Tassel's excellent legal defence team, led by Harold B. Lilley, the son of Queensland's Chief Justice, Sir Charles Lilley, ensured that no charges were laid. ${ }^{8}$ In spite of this death, and the obvious failure of the lady parachutist to achieve the heights claimed in their advertising, things did not turn nasty until Gladys Van Tassel/Freitas performed in Townsville, at Acacia Vale Gardens, on Sunday, 22 June 1890. The previous day, a Townsville delegation," led by Reverend James Stewart, had sought to have the exhibition banned because it would 'desecrate the Sabbath'. Reverend Stewart, who had arrived in Townsville on June 12 on the Bulimba, was from the Brisbane City Mission, an evangelical social welfare organisation. Stewart was ostensibly in Townsville to visit his brother, although there is evidence to suggest that he had 


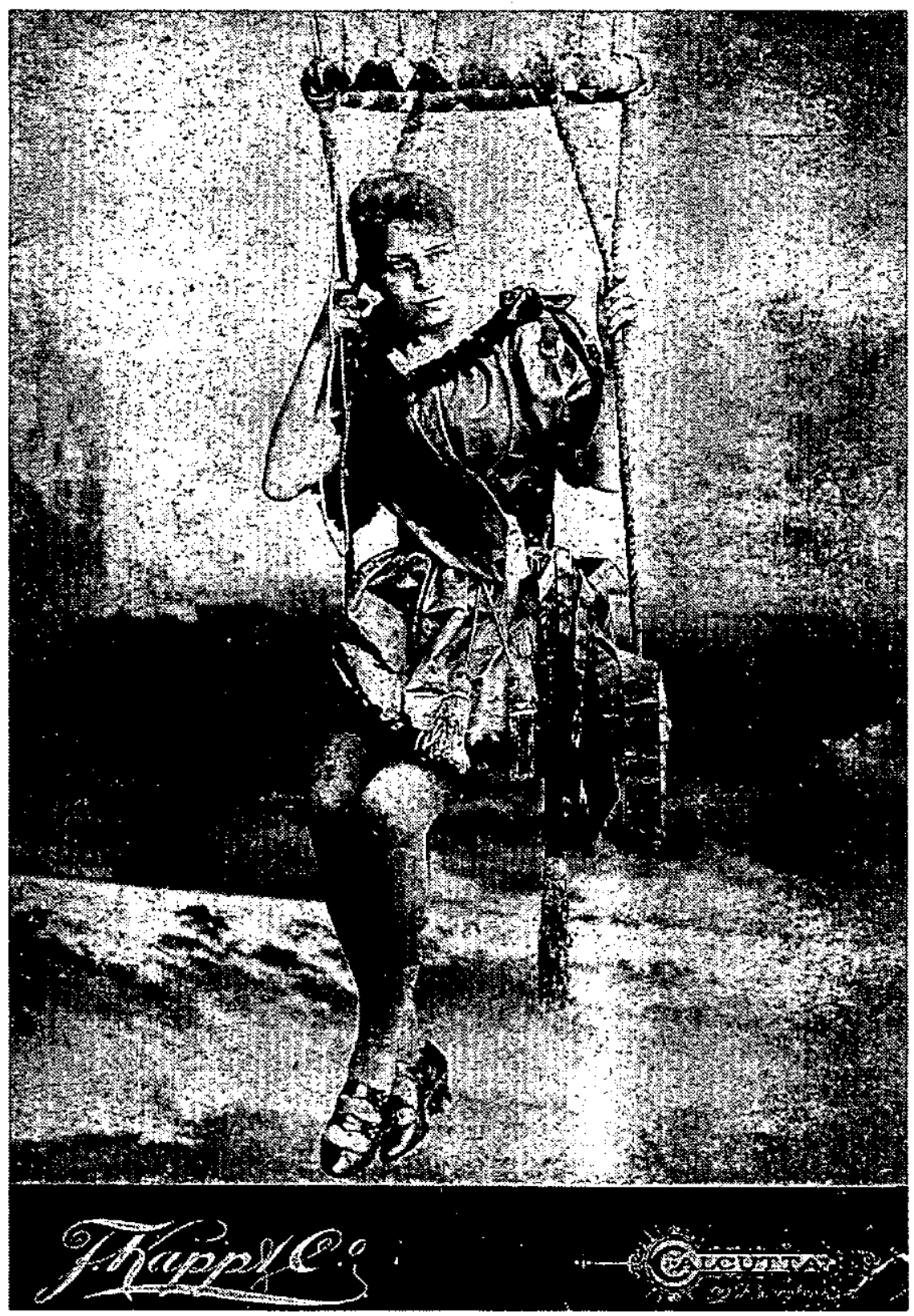

The real Miss Jenny Van Tassel (c. 1872-92), daughter of Park Van Tassel, suspended under her hot-air/smoke balloon and wearing the 'Lady Parachutist' costume which so outraged Queenslanders. She was killed in a parachute accident in India in March 1892. 
travelled there specifically to try to stop Van Tassel's 'sinful show'. Stewart was known throughout Queensland for his vigorous open-air preaching and rigid views on the strict observance of the Sabbath.

Stewart was unable to induce the Townsville magistrate, John G. MacDonald, or the local police chief, Inspector John B. Isley, to act because neither could find any legal grounds for banning this parachute exhibition. Stewart and his delegation then sought, by urgent telegram, to obtain a clear direction from the government in Brisbane to force the cancellation of the show, but no response was received. ${ }^{10}$ Reverend Stewart was particularly angry with the Van Tassel troupe because he was a neighbour of young Thomas Reid, who had been killed two weeks earlier in Brisbane through Van Tassel's negligence.

Coincidentally, Colonel G. French, Major C. Des Vœux, Major W. Ralston, Major P. Ricardo and many other senior officers of the Queensland Military Force also happened to be in Townsville that weekend for a major military encampment. Instead of their regular Sunday Church Parade and route march, the soldiers requested permission to attend the Miss Van Tassel parachute performance. Colonel French agreed, so almost all the officers and much of the Queensland Defence Force, numbering over 600 men, accompanied by squads of school cadets and the military band, marched to Acacia Vale Gardens, Townsville, to observe and take part in this spectacle." Colonel French and Major Des Vœux had already established a relationship with the Van Tassel performers when they all travelled together aboard The Barcoo, arriving in Townsville on 18 June. $^{12}$

A crowd estimated at between 2000 and 'half the Townsville population'13 showed up to watch Miss Van Tassel's balloon ascent and parachute jump. Those in attendance were said to include 'most of our leading citizens who are generally regarded by their fellow townsmen as honorable men and women' ${ }^{14}$ Reverend James Stewart and two supporters ${ }^{15}$ tried to interrupt proceedings, loudly protesting against this 'desecration of the Sabbath', and pointing out that such amusements were 'bringing disgrace upon Townsville, upon Queensland, upon the British nation'. ${ }^{16}$ To prevent violence from the crowd who were anxious to watch Miss Van Tassel, the police removed these protesters, who then confronted the military officers, beseeching them to order their troops and cadets away from these scenes of iniquity, but again with no success.

Van Tassel's balloon was made from calico 'made airtight by being soaked in a composition, and, when inflated it resembled a huge pear in shape, its height being $78 \mathrm{ft}$ [ 24 metres] ${ }^{\prime} .{ }^{17}$ The balloon was about 6.5 metres in diameter. The crew dug a trench about 750 centimetres deep and 10 metres long, then covered this over to make a tunnel. ${ }^{18}$ Over one end, they suspended the balloon from long poles, then lit a fire of 'splinters of pine saturated with a mixture of gasoline and alcohol'19 at the other end. 'The hot air and necessarily also the smoke from this furnace, was conducted ... into the balloon where it formed a great raising power. ${ }^{20}$ The expanding balloon was tethered to the ground by numerous ropes, which were held down by volunteers.

The parachute was made from 'stout linen', about 5 metres across 'in the shape of an umbrella, the ropes from its outer edges inclining in to the iron hoop'. ${ }^{21}$ 
-SOEM YInOS MON Jo KJEAq!T

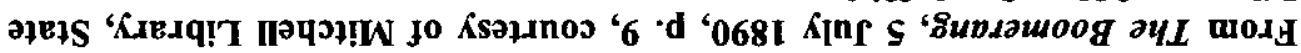

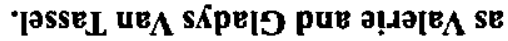

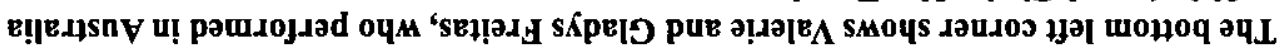

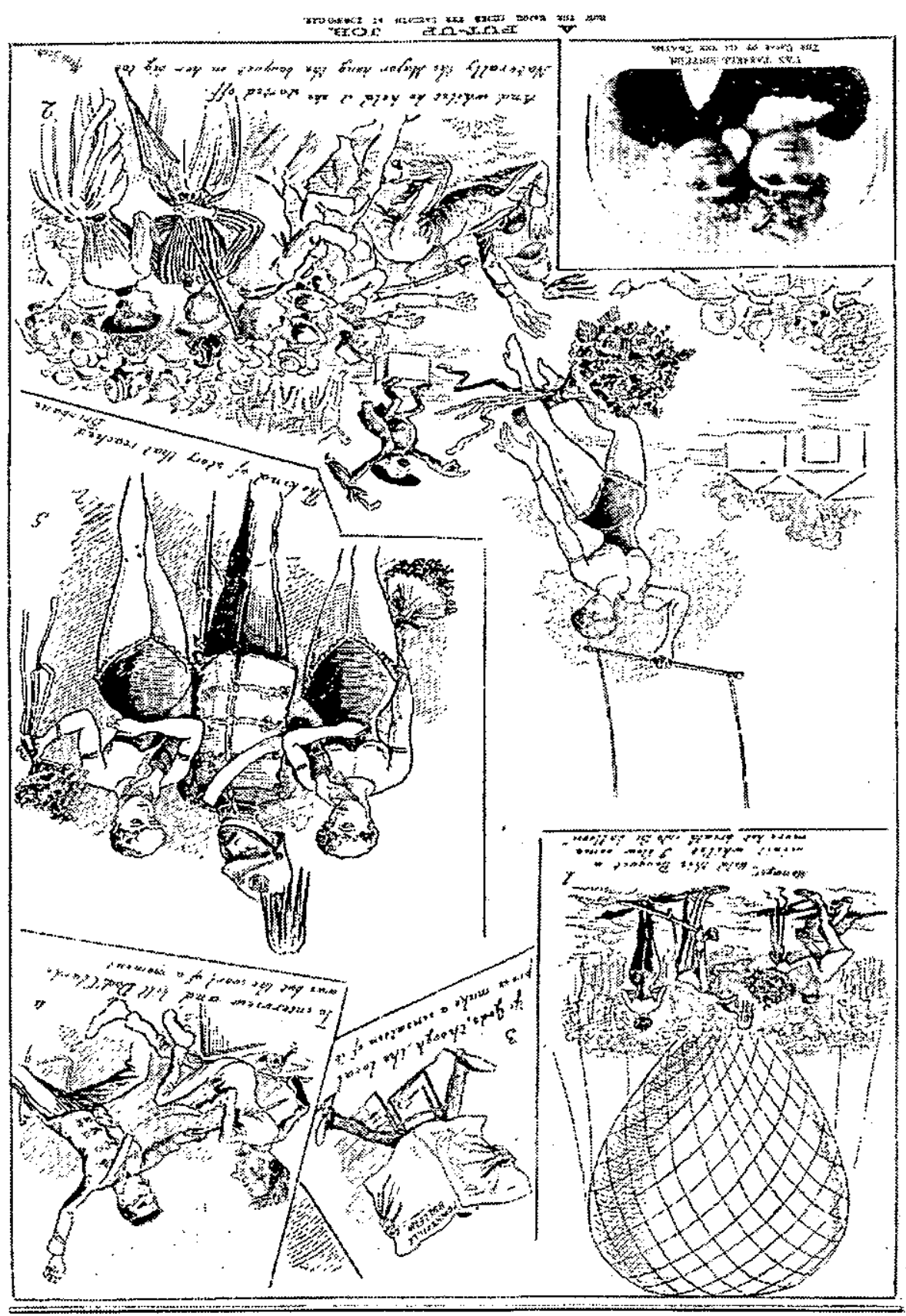

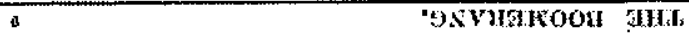

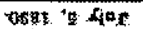


The parachute 'was attached to the bottom of the balloon, and to the bottom of the parachute was fastened, with long cords, a stout short bar, similar to that with which ordinary trapeze performances are given'. ${ }^{22}$

After between 45 minutes and two hours, when the balloon was fully inflated with hot air and smoke, the ropes would be released and the balloon would shoot upwards, lifting Miss Van Tassel, who would then perform various dramatic stunts on the trapeze bar, including hanging upside down suspended by her feet.

As the hot air and smoke cooled, the balloon would stop rising and then begin to descend, causing the parachute to open. The parachutist would then release the cord tethering her parachute to the balloon, and descend slowly to a nearby open space, performing acrobatic stunts until she was close to the ground. 'When nearing earth Miss Van Tassell [sic] holds the trapeze with her hands, gives the parachute a slanting cast and alights uninjured on her feet, the parachute falling a few feet further on. ${ }^{23}$ The deflated balloon usually landed nearby. ${ }^{24}$ She had some slight control over the direction of descent, depending on how she shifted her weight on the trapeze bar. ${ }^{25}$ Her entire performance usually lasted only a few minutes. She wore 'the usual professional costume of athletes', specifically a 'blue bodice and tights of the same colour'. Nevertheless, her critics often focused upon what they considered to be her 'unseemly' dress and actions. One reporter rapturously said that 'Miss Van Tassell [sic] is a veritable tassel when she hangs from that parachute'. ${ }^{26}$

In Townsville, at about 5.00 p.m. on Sunday, 22 June 1890, this hot air balloon - having been held down by Queensland Defence Force troops - was released. Gladys Van Tassel/Freitas accepted a bouquet of flowers from Major Des Vœux, ${ }^{27}$ then she soared to a height of perhaps 1200 metres before releasing herself and descending safely to Earth, clutching the trapeze bar which was secured to her parachute, and cheered by the crowd. ${ }^{28}$ She 'cleverly avoided a bed of pineapples' before landing in the garden of Alexander West. Then, much to the disgust of Reverend Stewart and the other protestors, she was welcomed back to Acacia Vale Gardens by the Queensland Defence Force band playing 'See the Conquering Hero Comes'. ${ }^{29}$

That would have been the end of the story had not the Townsville Bulletin greatly embellished the details, alleging that the soldiers had been ordered, against their will, to attend and to help with the display, that innocent school cadets had been forced to witness this scandalous behaviour, and that Colonel French and Major Des Vœux had thereby insulted Queen Victoria, God and the Queensland taxpayers. The Editor wrote that, if Colonel French:

perceived nothing scandalous in the spectacle of a uniformed member of his headquarters staff presenting on his knees, a bouquet of flowers to a female aeronaut, in the presence of half Townsville on a Sunday afternoon, it is idle to expect that such a matter as forcing some hundred schoolboys to assist at this Sunday exhibition will seem in any way objectionable to him. ${ }^{30}$ 


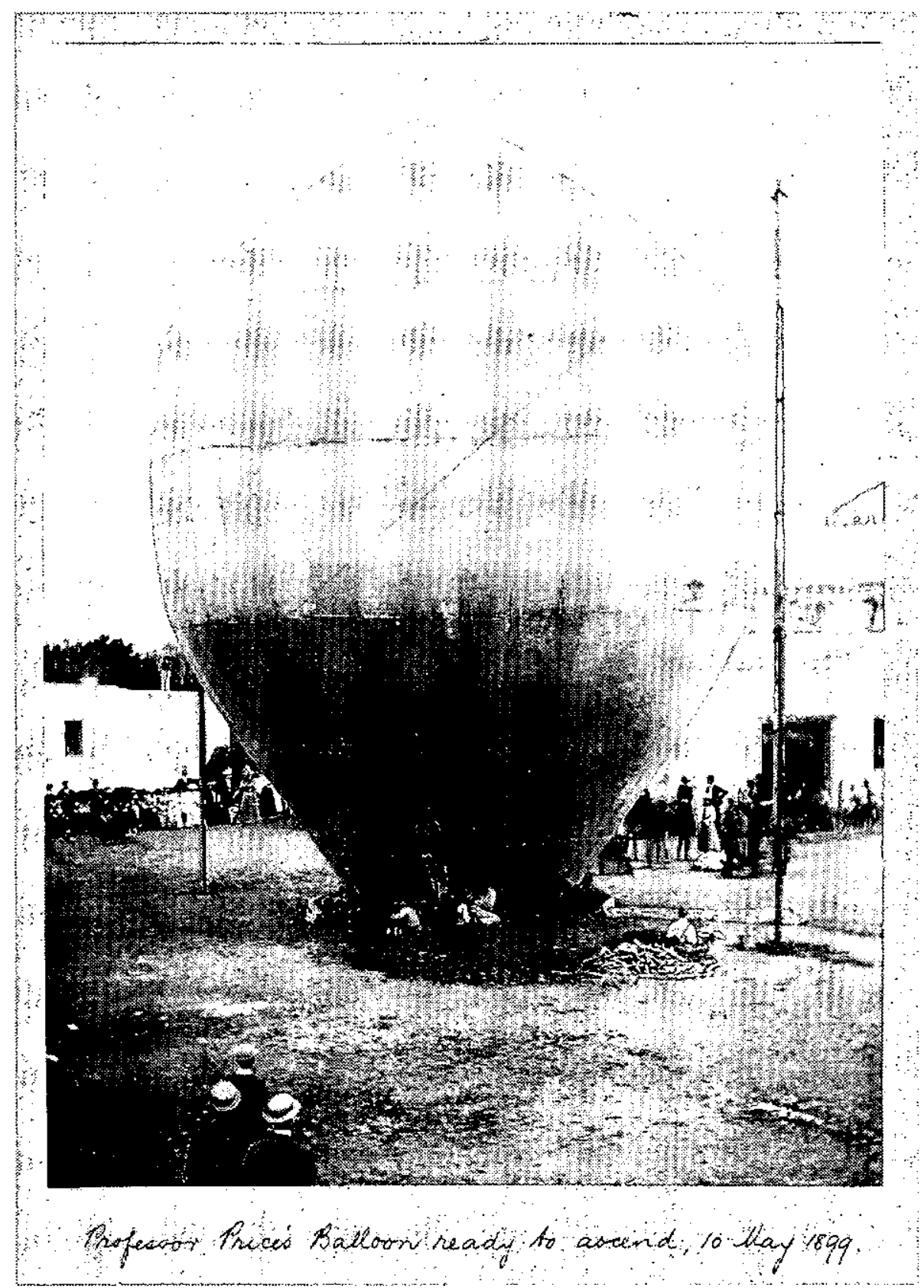

This is either the original or a replacement of the fully inflated hot-air/smoke balloon used by the Van Tassel Parachutist Team. The photo shows a man stoking the fire in a pit on the lower right, the smoke and heat from which goes through a tunnel, covered by fresh earth, and 20-30 men holding down the balloon. The 'lady parachutist' and her parachute can be seen on the right above the fire-stoker.

Photo from Photographic Collection of the Graaff-Reinet Museum, Eastern Cape, South Africa. The photographer was William Roe, 1899. 


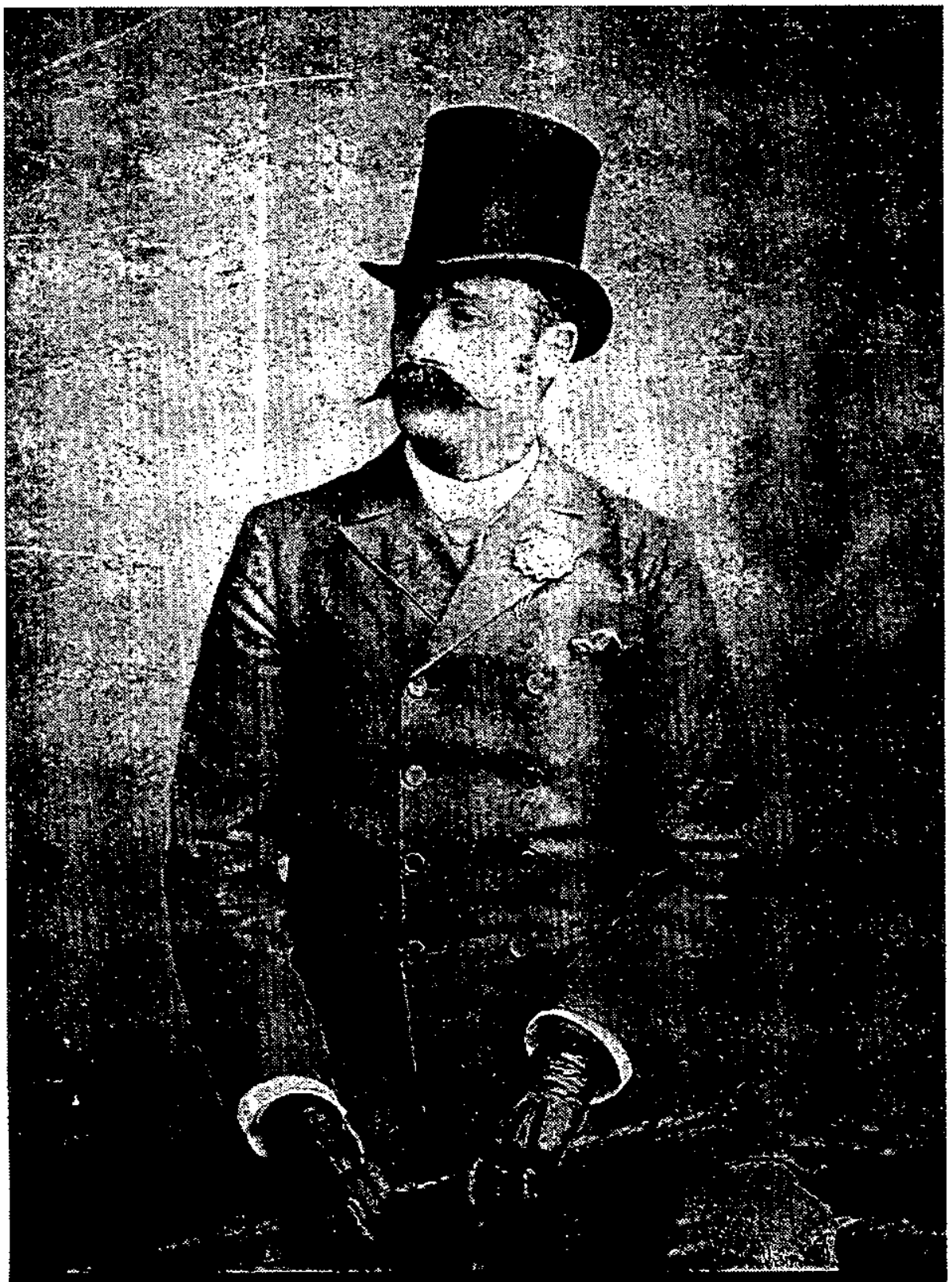

thenante.:

$1-1$

Park Van Tassel (1852-1930), dressed as the consummate showman. Photo taken in India in 1892, courtesy of Rick Van Tassel. 
Other local papers supported Townsville residents' rights to enjoy such entertainment on a Sunday, and roundly condemned Reverend Stewart, with one paper calling him a "canting and hypocritical "snufflebusting" 31 ... puritanical gentleman' whose 'religious enthusiasm carried him very far beyond the bounds of prudence and common sense, and far into the realms of idiotic bigotry and uncharitableness'. His behaviour 'insults our nineteenth century civilization and intelligence by telling us that we are sinning against Divine Law by indulging in a little harmless recreation on our Sunday afternoon'. ${ }^{32}$

The Brisbane Courier, ever ready to indulge in sectarianism, eagerly stepped into the fray, supporting Reverend James Stewart's 'brave and wise protests', and roundly condemning Premier Morehead for not stopping 'the scandal of the Sunday exhibition'. The editor argued that 'it was outrageous that our military representatives should by their presence and encouragement implicate the country in a violation at once of decency and of religious conviction'. Alluding to the immoral nature of Miss Van Tassel's performance, the Brisbane Courier noted that, while 'innocent exhibitions might easily be tolerated on Sunday ... exhibitions on the contrary which are inherently demoralising and objectionable therefore on any day of the week, are precisely those which come boldly forward to outrage the sacred convictions of the people'. Such a display, the editor alleged, would not have been attempted in Brisbane, where the dubious character of the Van Tassels was well known, but he then deprecatingly observed: 'It is a far cry to Townsville. ${ }^{33}$

Two days after the balloon ascent and parachute descent, MLA Andrew $\mathrm{H}$. Barlow raised the issue in parliament:

I was exceedingly sorry to read what occurred at Townsville.

I wish to draw the attention of the Premier ... to the fact that the Defence Force of this colony are represented as having taken part in their official capacity in a proceeding which we must all deeply regret. I am not going to enter into the religious aspect of the question, but I do say that from the hon. Gentleman who sits in front of me, who works with his head, down to the least paid man who works with his hands, if the sanctity of the seventh day as a day of rest is impaired and undermined, the result will most certainly be that there will be seven days' labour for six days' pay. ${ }^{34}$

On the following day, with no response from Premier Morehead, the issue was again raised in parliament, this time by MLA John Macfarlane, who said that 'in Townsville on Sunday last, an Exhibition, being a Balloon Ascent, took place at which money was taken at the gate, in spite of the protest of many inhabitants'. He asked: 'Was such information received in time to stop the Exhibition?' and 'Does the Government intend to make any inquiry into the matter?' Morehead replied that he had been advised in time to stop the performance, "but the information afforded no grounds upon which action could be taken'. Morehead promised to pursue the matter. ${ }^{35}$ 


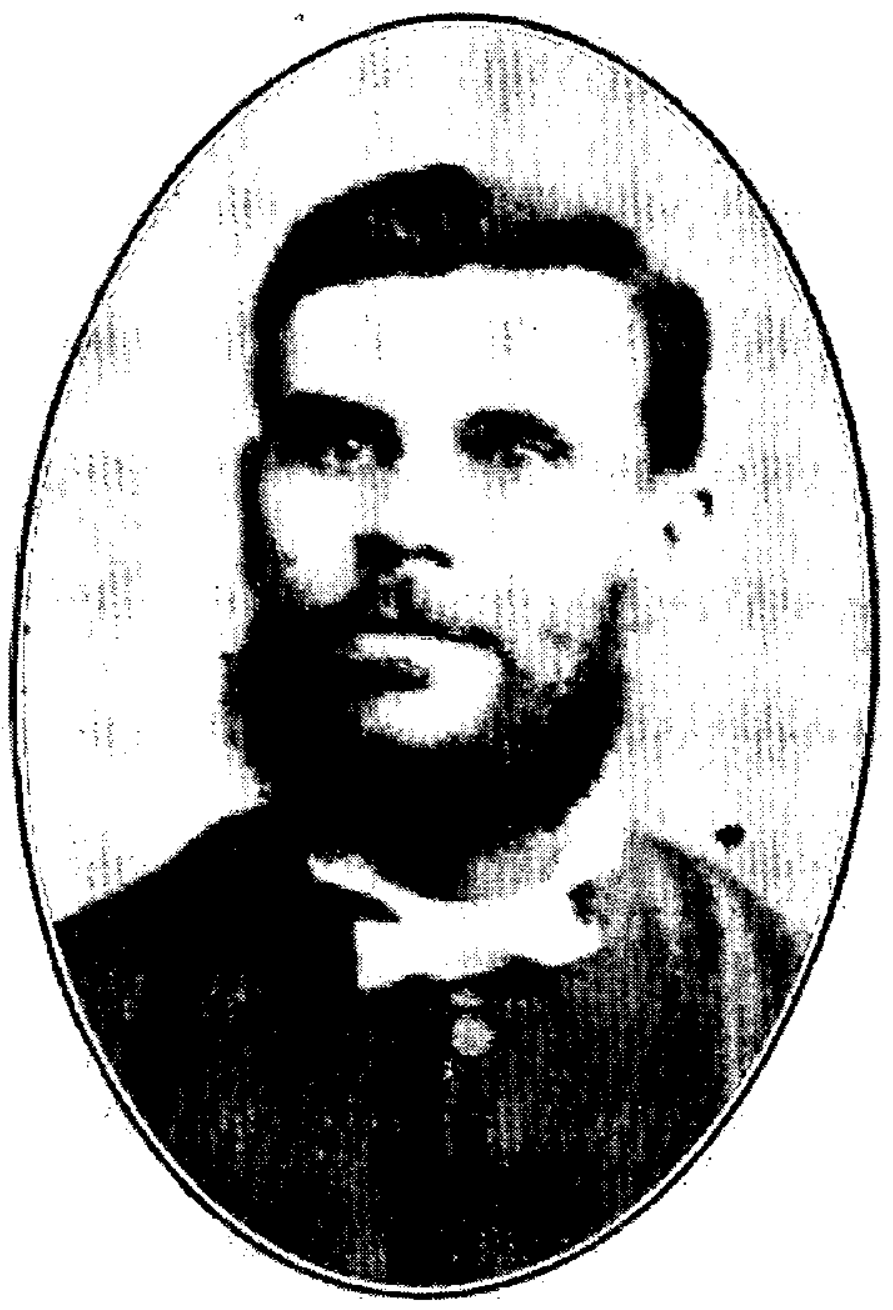

REV. JAS. STEWART, 1878.1881.

J. Stewart, Photograph courtesy of John Sinclair, Archivist, Presbyterian Church of Queensland. 


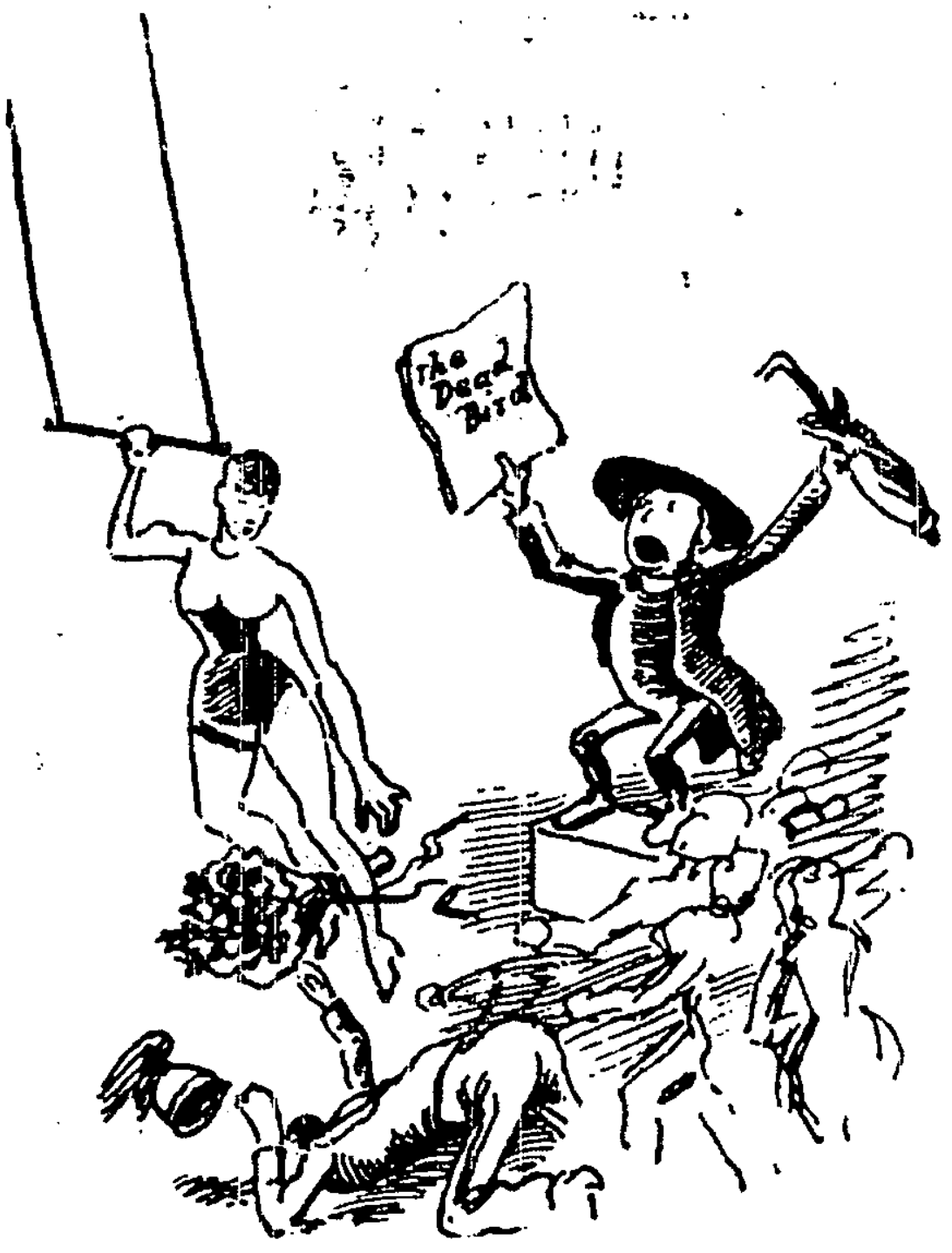

Miss Van Tassel holds on to the gymnastic bar suspended from the balloon and begins her ascent, Reverend James Stewart harangues the crowd from his podium, and Major Des Veux falls flat on his face and drops the flowers which he was presenting to Miss Van Tassel.

From The Boomerang 19 July 1890, p. 9. 
Suddenly, this incident escalated into a major Queensland scandal, consuming much space in newspapers and much time in parliament and high government circles. Reverend William O. Lilley, of Ann Street Methodist Church, referred to 'The Outrage at Acacia Vale' and preached against the desecration of the Sabbath. He also chastised Professor Van Tassel by observing that 'no father who cared for his daughters, and no brother who cared for his sisters would like them to expose themselves to the risk of loss of life, and in the manner the Van Tassels did'. Lilley went on to describe Colonel French and Major Des Vœux as being 'the mere refuse of the British Army, sent out here', for which be was threatened with a libel suit. ${ }^{36}$

Meanwhile, Reverend William Whale, of Wharf Street Baptist Church, preached on 'our need of defence against the defence force', and rhetorically asked 'whether the people should rule the army, or the army rule the people?' He pointed out that 'objectionable matters' (i.e. pornography) were available at military encampments, making them a danger 'to the young boys of the Cadet Corps, and the young men of the Volunteer and other forces'. This danger was all the more serious because of the obvious moral laxity of the two Misses Van Tassel and their American entourage ${ }^{37}$ Reverend Whale was then also issued with a writ for libel by Colonel French and Major Des Vœux. ${ }^{38}$

On the following Sunday, Reverend George D. Buchanan, of Wickham Terrace Presbyterian Church, preached that this Lady Parachutist affair was only 'a flutter in the teapot', and said that 'it amused him to see what little things commanded attention here'. He sermonised against the 'intolerable curse of intolerance' as demonstrated by his fellow Christian ministers. Reverend Buchanan saw no danger in 'the goddess of the clouds' performing on Sunday, and concluded that 'the only danger to the Church ... was in this intolerant spirit' ${ }^{39}$ Buchanan had advised the Queensland Defence Force on the subject of his sermon, so several hundred soldiers had crowded into his church. ${ }^{40}$

A special meeting of the Lord's Day Observance Society was called, at which Rev Buchanan's liberal approach to this affair was roundly rejected, and Reverend James Stewart's intervention applauded. This meeting condemned Gladys Van Tassel's 'indecent exhibition' and 'public scandal', and alleged that Queensland was now threatened by 'militarianism' [sic] because the Defence Force leadership did not respect the Christian values of the community."

Reverend Lilley further inflamed the issue on 13 July by preaching against 'the curse of tolerance', and arguing that to tolerate scandalous displays such as those by the Lady Parachutists would lead to 'the inrushing wave of lawlessness and anarchy which, in the name of liberty, seemed ready to engulf them'. Reverend Whale followed suit, preaching against 'the curse of intolerant toleration'. Whale claimed that his 'threat from Colonel French of a criminal action for libel' was further evidence of the evil resulting from this scandalous performance. Political pressure from both within and outside his church now forced Reverend Buchanan to quickly recant his liberal opinions, toe the parochial line and preach the importance of the 'proper observance' of the Sabbath. ${ }^{42}$ 
Meanwhile, Queensland Premier Boyd Dunlop Morehead, under political pressure, sought to shift the public outcry away from himself and his failure to stop this performance when he had the chance. Archival records show that, when Morehead's intervention had first been requested, he had sought a confidential legal opinion from Queensland's Minister of Justice, Andrew J. Thynne, and had been told that 'there is no statute which I can find which renders the proposed balloon ascent a penal offence ... There appears to be nothing in the imperial statutes relating to Sunday observance ... applicable to the case. I am unable therefore to advise, at present, that any legal steps should be taken to prohibit the proposed balloon ascent. ${ }^{93}$ This legal advice, however, was never made public.

Nevertheless, in spite of advice from the Minister of Justice that there were no legal grounds for stopping the Miss Van Tassel parachute jumps, Morehead met with Reverend James Stewart, ${ }^{44}$ and then inexplicably and illogically accused the military of militarism. He demanded full explanations from Major Des Voux and Colonel French for their 'scandalous behaviour'. Des Vœux denied any wrong-doing, and glibly wrote that he was only trying to be a decent chap while handing flowers to the 'female acrobat'. He alleged that he was being vilified by religious fanatics such as Reverend Stewart 'from their idea of a highly moral and religious standpoint'. ${ }^{45}$

Colonel French wrote to Premier Morehead in more restrained tones, explaining that 'a long military experience has convinced me that the religious principles of their men, or the absence thereof, are matters with which superior officers had better not interfere'. Colonel French said that he had happily agreed to his men attending the Lady Parachutist entertainment, and he described the subsequent outcry as a 'tissue of falsehoods [which] scarcely requires denial in detail'. French pointed out that:

the men who assemble in Townsville Camp are mostly independent, high-spirited fellows, and that they would resent any suggestion to the effect that because they voluntarily undertook military obligations they were thereby deprived of any of their civil rights. I have no fault to find with any spontaneous enthusiasm to which they may have given expression at seeing a feat performed by a woman which probably few of them would have dared to attempt. ${ }^{46}$

Because he was under political pressure from Christian conservatives, Premier Morehead angrily and hypocritically rejected both officers' explanations, and took up the side of the maligned Reverent Stewart and the Lord's Day Observance Society. Morehead publicly threatened to remove Colonel French from his position as Commandant of the Queensland Defence Force, and concluded that Colonel French should be charged with 'neglect of Duty in not preventing what I hold to have been nothing less than a public scandal' ${ }^{47}$

In the face of threatened dismissal from his $£ 900$-a-year position, Colonel French quickly relented, publicly admitted that he had inadvertently acted outside the law (although he had not), and wholeheartedly apologised for any embarrassment his actions had caused the government. French humbled himself, saying: 
I have now to express my very great regret for placing myself in the wrong, even technically, in this matter $\&$ for permitting others to do so, \& ... I beg to request that any censure may be confined to myself, as I now take the whole responsibility for the presence of members of the Defence Force on the occasion referred to, and the consequences thereof. ${ }^{48}$

This apology was sufficient for Colonel French to retain his position as leader of the Queensland Defence Force. Within months, French was called upon by the Premier to demonstrate his loyalty when he had to lead his troops against the striking Shearers' Union members at Barcaldine - a duty he performed with cold determination and a will of steel. ${ }^{49}$

Colonel French's humble submission to the hypocritical cant of Reverend Stewart, the Brisbane Courier and Premier Morehead sufficed to dampen down this affair. The newspapers soon lost interest and this tempest in a colonial teapot was over - except in the embittered memory of Methodists and Sabbatarians such as the Reverend James Stewart and his fellow parishioner, Dr Thomas Pennington Lucas. They saw this episode as symptomatic of 'modern', un-Christian ways, and a threat to civilisation. As already mentioned, Lucas then used this Lady Parachutist scandal as the central event in his 1894 dystopian novel, The Ruins of Brisbane in the Year 2000.

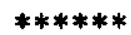

The most obvious and simple reason why the Lady Parachutist episode caused such an uproar is that it happened on a Sunday and an entrance fee was charged; the event thereby 'desecrated the Sabbath'. This, however, does not stand up to analysis simply because the newspapers regularly reported a wide range of Sunday entertainment for which admission fees were charged. These ranged from football games, fireworks and excursions to musical recitals and circus performances. While holding such performances on a Sunday may have been objectionable to some people, this does not explain the sense of outrage over the Lady Parachutists. The Lady Parachutists had performed several times previously in Queensland, and had evoked little opposition and even a small amount of media admiration - - so this young woman's act of ascending in a hot-air balloon then returning to earth via a parachute was not the problem per se.

A close reading of the numerous newspaper and archival accounts of this Lady Parachutist episode suggests that the outrage was caused by the combination of four factors. First, it concerned a scantily clad and very competent and attractive young woman acting in what were seen to be 'unladylike' ways which were central to the attraction. Second, the Queensland Defence Force and cadets were present at this sexually charged performance. Third, this all happened on a Sunday, when one of Queensland's most dogmatic wowsers, Reverend James Stewart, was present. And, finally, Premier Morehead opportunistically opted to ignore legal advice and take advantage of the hysteria for cheap political gain over liberals 
such as Samuel Griffith. As well, deeper issues of sexual politics and culture were almost certainly at stake.

Victorian gender prescriptions were rigid and precise. Women - particularly young women - were seen to be technically incompetent, fearful of danger and socially shy. Their sexuality was to be under absolute control - if not non-existent. For an attractive young woman to be in charge of the cutting-edge technology of flight, and to launch herself bravely into space with only a thin parachute for protection while wearing only a skimpy outfit which revealed her legs and arms was to flaunt her sexuality and competence. She was far too exciting! Female sexuality, when out of control, was dangerous. ${ }^{50}$

Also, a frequent medical and spiritual concern at this time was the danger to men from masturbation. This 'unspeakable act' deprived a man of his true manhood, ruined his concentration and could thereby weaken the nation. 'Pedagogues, doctors, parents, priests, and clergymen ... contemplated among the young an epidemic of vice. ${ }^{51}$ Australian medical experts offered to help any man who, through masturbation, 'in his youth has trifled away his vigour of body, mind, and manhood' ${ }^{52}$ Brisbane speakers showed graphic images, and offered lurid accounts, of 'the state of degradation to which those who practise vicious and immoral habits could be reduced'. ${ }^{33}$ Masturbation was a danger to all men, but particularly to all-male groups such as those at military camps, where pornography was known to be available. This danger was all the more obvious, however, when boys were also present, as was the case with the cadets at Townsville. Reverend Stewart 'pitied - sincerely pitied - the young men who were exposed to such temptations, and especially did he pity the Cadet boys' ${ }^{54}$

The Lady Parachutist scandal probably arose because Miss Van Tassel flaunted her competence, beauty and sexuality in front of an almost all-male audience. Wearing scanty costumes, she attracted male attention, admiration and lewd thoughts. Should these sights lead to self-abuse on the part of the soldiers - and, even worse, the cadets - their usefulness as models of British manhood, and even their ability to protect Queensland, would be in grave doubt. Indeed, in $1885 \mathrm{Dr}$ Thomas Pennington Lucas, a colleague of Reverend Stewart, had written a book on these very dangers, entitled Do Thyself No Harm: A Lecture to Men. ${ }^{55}$

And, four years after the Lady Parachutist scandal, that is precisely the scenario which Dr Thomas Pennington Lucas posited in his dystopian novel, The Ruins of Brisbane in the Year 2000, wherein the Queensland Defence Force men are so mesmerised and aroused by the spectacle of Lady Parachutists that they are unable to do their duty and defend Queensland. Their very manhood has been sapped by viewing such lewd scenes and perhaps - we can only guess - by the resultant plague of masturbation. This, in Dr Lucas's view, was sufficient to lead to the end of civilisation in Queensland. 


\section{Notes}

1 Thomas P. Lucas, The Ruins of Brisbane in the Year 2000, published in The Curse and its Cure (Brisbane: J.H. Reynolds, 1894).

2 New York Times, 26 October 1930, p. 24; emails dated 17 and 19 January 2005 from Rick Van Tassel to the author; and http://freepages.genealogy.rootsweb.com/vantasselfamilyhistoryhomepage. The Van Tassel acrobatic group had arrived in Sydney on 12 December 1889 on the Mariposa. The surname was spelt as 'Van Tassell', 'Van Tasel' and 'Van Tassel', but the latter seems to be the preferred spelling and is used herein except when citing sources which use other versions.

F. Mines, A Draft of Parachuting in Australia up to the Foundation of Sport Parachuting in 1958, undated paper (http://esvc001114.wic013u.server-web.com/news/History-of-AustralianParachuting-from-1958.pdf); Sydney Morning Herald, 26 November 1937, p. 12; and Queensland State Archives (QSA): SRS36, Inquest Files, Con. 5, Item 177, 1890.

The Argus, 2 February 1858, p. 5; and Melbourne Age, 2 February 1858, p. 4.

$5 \quad$ Melbourne Age, 15 April 1879, p. 3; and The Argus, 15 April 1879, p. 5.

$6 \quad$ The Bulletin, 15 December 1888, p. 7.

7 Mines, A Draft of Parachuting in Australia; Encyclopedia Britannica; various web sites; and Sydney Morning Herald, 10 December 1888, p. 4.

QSA: SRS36, Cons. 5, Item 177, Inquest into Death of Thomas Reid; Brisbane Courier, 4 June 1890, p. 3; Northern Age, 21 June 1890, p. 2.

The delegation included Reverend Alexander Gauld, James Deichanty, Thomas Page, Thomas Whaley, Anthony Shanks, James Noble, James Church, E. Glagholm, William Trewin and Peter Nielson. Townsville Evening Star, 21 June 1890, p. 2; Northern Age, 21 June 1890, p. 2. Northern Age, 21 June 1890, p. 2; The Queenslander, 28 June 1890, p. 1205. QSA, COL/A621, \# 7387 of 1890 , letter 7346. Townsville Evening Star, 18 June 1890, p. 2; Townsville Herald, 21 June 1890, p. 25.

The Townsville Herald, 28 June 1890, p. 13; Northern Age and North Queensland Telegraph, 23 June 1890, p. 2; Townsville Evening Star, 23 June 1890, p. 2.

Townsville Evening Star, 23 June 1890, p. 2.

15 Reverend Thomas Ellison and Frederick Yarrow.

16 Northern Age and North Queensland Telegraph, 23 June 1890, p. 2.

17 Brisbane Courier, 23 May 1890, p. 6; and emails from David Craddock to author dated 1 June and 12 July 2005 .

18 The Townsville Herald, 28 June 1890, p. 13.

19 Brisbane Courier, 23 May 1890, p. 6.

20 Brisbane Courier, 23 May 1890, p. 6.

21 The Townsville Herald, 28 June 1890, p. 13.

22 Brisbane Courier, 23 May 1890 , p. 6.

23 The Townsville Herald, 28 June 1890, p. 13.

24 According to Australian balloon researcher, David Craddock: 'The parachute was fixed by an ingenious arrangement to the bottom of the balloon (the open mouth part of the balloon for inflation), and by simply pulling a string (that went up to where the parachute was attached), the parachute could be disengaged. So, picture this: the inflated gas bag at the top, then attached to some simple structure across the bottom of the balloon is the apex of the parachute. Now, the parachute and a light cord (or string) hang down, under the weight of the aeronaut who is holding on to the bar at the bottom of the parachute cords. When she released the parachute, by pulling on the string, the balloon would just float or turn over and eventually land. The balloon would have no cords attached at that time. The parachute drops after release and soon fully inflates and descends to the ground with its passenger holding on to the trapeze bar.' Email dated 1 June 2005, from David Craddock to author. 
Brisbane Courier, 23 May 1890, p. 6; Northern Age, 21 June 1890, p. 2; Northern Age, 23 June 1890, p. 2; The Townsville Herald, 28 June 1890, p. 13.

According to Townsville Evening Star, 23 June 1890, p. 2, this disputed bouquet had actually been handed to Miss Van Tassel by Steve Byrne.

Northern Age and North Queensland Telegraph, 23 June 1890, p. 2.

The Queenslander, 5 July 1890, p. 33.

Townsville Bulletin, 23 June 1890 (quoted in Brisbane Courier, 27 June 1890, p. 3; repeated in The Townsville Herald, 28 June 1890, p. 13).

This quaint term means 'wowser' according to the Macquarie Dictionary, and 'puritanical' according to J. Hughes (ed.), Australian Words and their Origins (Melbourne: Oxford University Press, 1989).

Charters Towers Times, 26 June 1890, pp. 1 and 2.

Brisbane Courier, 26 June 1890, p. 4.

Queensland Legislative Assembly, Parliamentary Debates, Vol. 3, 1890, p. 48.

Queensland Legislative Assembly, Votes and Proceedings, Vol. 1, 1890, p. 18.

Brisbane Courier, 30 June 1890, p. 6; and W. Osborne Lilley, Reminiscences of Life in Brisbane and Reflections and Sayings (Brisbane: W.R. Smith, 1913): 162.

Brisbane Courier, 30 June 1890, p. 6.

Lilley, Reminiscences: 162.

Brisbane Courier, 7 July 1890 , p. 6 .

Lilley, Reminiscences: 162-63.

Brisbane Courier, 12 July 1890 , p. 5.

Brisbane Courier, 14 July 1890, p. 6; Lilley, Reminiscences, pp. 161-63.

QSA COL/A620, \# 7089 of 1890 , letter 7089 .

Brisbane Courier, 12 July 1890 , p. 5.

QSA, COL/A621, \# 7387 of 1890, letter 3903.

QSA, COL/A621, \# 7387 of 1890 , letter 7346.

QSA, COL/A621, \# 7387 of 1890 , Minute by the Chief Secretary.

QSA COL/A621, \# 7387 of 1890, letter 7387; The Queenslander, 12 July 1890, pp. 54-55.

Stuart Svenson, The Shearer's War: The Story of the 1891 Shearer's Strike (St Lucia: University of Queensland Press, 1989): 146.

See, for example: J. Allen, Rose Scott: Vision and Revision in Feminism (Melbourne: Oxford University Press, 1994); and M. Lake, Getting Equal: The History of Australian Feminism (Sydney: Alien \& Unwin, 1999).

W. Laquer, Solitary Sex: A Cultural History of Masturbation (New York: Zone Books, 2003), p. 231 .

For example: Professor Carl Stineway, in The Bulletin, 12 July 1890, p. 1; and Dr Richards in The Townsville Herald, 28 June 1890, p. 32.

Brisbane Courier, 14 July 1890, p. 6.

Brisbane Courier, 12 July 1890 , p. 5.

Thomas Pennington Lucas, Do Thyself No Harm: A Lecture to Men (Melbourne: Mason, Firth and McCutcheon, 1885). 